\title{
Cultivation of microbes from the deep-sea environments
}

\author{
Zenghu Zhang ${ }^{\mathrm{a}, \mathrm{c}}$, Yanhong $\mathrm{Wu}^{\mathrm{a}}$, Xiao-Hua Zhang ${ }^{\mathrm{a}, \mathrm{b}, *}$ \\ a College of Marine Life Sciences, Ocean University of China, Qingdao 266003, China \\ b Laboratory for Marine Ecology and Environmental Science, Qingdao National Laboratory for Marine Science and Technology, Qingdao 266071, China \\ ${ }^{c}$ Research Center for Marine Biology and Carbon Sequestration, Qingdao Institute of Bioenergy and Bioprocess Technology, Chinese Academy of Sciences, Qingdao \\ 266101, China
}

\section{A R T I C L E I N F O}

\section{Keywords:}

Deep-sea microbes

Piezotolerant

Piezophilic

Cultivation methods

\begin{abstract}
A B S T R A C T
The deep-sea environment has rich microbial resources, and these resources have been an important subject in the efforts to culture microflora. Special devices that maintain in situ pressures have been developed and applied in culturing piezophilic and hyperpiezophilic microbes. However, culturable microorganisms comprise the minority of deep-sea microbes (archaea and bacteria), which reflects the disadvantages of traditional cultivation methods, the ignorance of microbial habitats, and the fastidiousness of microbial growth requirements. This mini-review introduces the diversity of microbes in the deep sea and discusses the deep-sea species that have been identified in the past two years. In addition, this review summarizes almost all of the recognized piezophilic microbes and describes the isolation methods that have been employed. Additionally, we recommend that some of the methods that have been developed to obtain microbes from surface water, freshwater, sediments, soils and organisms should be modified to enable the isolation of the deep-sea microbes. It is anticipated that this minireview will provide novel insights into exploration of "uncultured" deep-sea microbial resources.
\end{abstract}

\section{Introduction}

Oceans cover $\sim 71 \%$ of our planet and have an average depth of $3800 \mathrm{~m}$ with an average pressure of $38 \mathrm{MPa}(380 \mathrm{~atm})$. The deep sea, which generally refers to the sea with a depth of $>1000 \mathrm{~m}$, accounts for $\sim 75 \%$ of the total ocean volume (Fang et al., 2010). The salinity of deep seawater is $\sim 35$, and the deep-sea temperature is $\sim 1-3{ }^{\circ} \mathrm{C}$ (Skropeta and Wei, 2014), except at hydrothermal vents, where the temperature can reach $460{ }^{\circ} \mathrm{C}$ at the heart of the chimney though the surrounding water may be only $2^{\circ} \mathrm{C}$ (Jebbar et al., 2015). The pH is 7.8-7.9 in most deep-sea locations that have been examined (Park, 1966; Tan et al., 2012). The deep ocean lacks sunlight because light can only reach to a water depth of $250 \mathrm{~m}$. Current speeds at the sea bottom are $\sim 10 \mathrm{~cm} \mathrm{~s}^{-1}$ at bathyal depths, and $\sim 4 \mathrm{~cm} \mathrm{~s}^{-1}$ at abyssal depths (Skropeta and Wei, 2014). Pressure increases by $1 \mathrm{~atm}$ for every 10-m depth increase. The oxygen concentration of bottom water in the deep northeast Pacific Ocean is $200-300 \mu \mathrm{mol} / \mathrm{kg}$ (Cai and Reimers, 1995), and D'Hondt et al. (2015) found that oxygen penetrates the entire sediment column underlying the South Pacific Gyre, where sediment slowly accumulates in a shallow layer. The concentration of dissolved organic carbon in the deep ocean is $\sim 35-48 \mu \mathrm{mol} / \mathrm{kg}$ (DeLong et al., 2006; Bercovici and Hansell, 2016). A variety of topographical features exist in the deep-sea environments, such as hydrothermal vents, cold seeps, oceanic trenches, seamounts, and bathyal plains, which possess different physical and chemical properties. The extreme environment supports a particular microbial community, which, in turn, affects the surrounding habitat.

All the above mentioned factors may have considerable influences on microbial life. However, most critical factors (in order of importance) are nutrient concentration, temperature, and hydrostatic pressure (Jannasch et al., 1982). Moreover, pressure effects on microbes are influenced by temperature. High hydrostatic pressure is a most significant physical characteristic of the deep sea, and distinguishes it from shallow seas. Thus, deep-sea bacteria may be considered as piezotolerant (growth from 0.1 to $10 \mathrm{MPa}$ ), piezophilic (growth from 10 to $70 \mathrm{MPa}$ ), and hyper-piezophilic (no growth at pressure lower than $50 \mathrm{MPa}$ ) based on their optimal growth pressures (Fang and Bazylinski, 2008). As piezotolerant bacteria do not have strict requirement of high pressure, they have been regularly cultivated and the diversity of piezotolerant bacteria is relatively high (Table 1 and Table 2). Piezophilic microbes have also been cultured, but their diversity is very low and mainly includes representatives of five bacterial genera belonging to $\gamma$ proteobacteria, i.e., Photobacterium, Shewanella, Colwellia, Psychromonas and Moritella, whereas piezophilic archaea are mostly (hyper-) thermophiles from Thermococcales (Oger and Cario, 2013). Obligate piezophilic microbes, whose activities are restricted by unique

\footnotetext{
* Corresponding author at: College of Marine Life Sciences, Ocean University of China, Qingdao 266003, China.

E-mail address: xhzhang@ouc.edu.cn (X.-H. Zhang).
} 
Table 1

Novel bacterial species isolated from deep-sea environments during 2014-2015 and their isolation methods.

\begin{tabular}{|c|c|c|c|}
\hline Methods & & Taxon & References \\
\hline \multirow[t]{10}{*}{ Plating methods using regular media } & Marine agar 2216 & Nocardioides pacificus & Fan et al. (2014a) \\
\hline & & Luteimonas abyssi & Fan et al. (2014b) \\
\hline & & Luteococcus sediminum & Fan et al. (2014c) \\
\hline & & Oceanobacillus pacificus & Yu et al. (2014) \\
\hline & & Achromobacter sediminum & Zhang et al. (2014) \\
\hline & & Roseivivax marinus & Dai et al. (2014) \\
\hline & & Salipiger nanhaiensis & Dai et al. (2015) \\
\hline & R2A agar & Desmospora profundinema & Zhang et al. (2015) \\
\hline & & Lentisphaera profundi & Choi et al. (2015) \\
\hline & & Marinithermofilum abyssi & Zhang et al. (2015) \\
\hline \multirow{2}{*}{ Plating methods using modified media } & Marine agar 2216 containing $\mathrm{MnCl}_{2}$ & Altererythrobacter atlanticus & Wu et al. (2014) \\
\hline & R2A agar containing cycloheximide & Cavicella subterranea & França et al. (2015) \\
\hline \multirow[t]{6}{*}{ Plating methods using special media } & Marine agar 216L & Mameliella atlantica & Xu et al. (2015) \\
\hline & & Marinibacterium profundimaris & Li et al. (2015) \\
\hline & & Zunongwangia atlantica & Shao et al. (2014) \\
\hline & FRPFO medium & Anoxybacter fermentans & Zeng et al. (2015b) \\
\hline & & Caloranaerobacter ferrireducens & Zeng et al. (2015a) \\
\hline & PAH medium & Celeribacter indicus & Lai et al. (2014) \\
\hline \multirow[t]{8}{*}{ Others methods } & Continuous-flow bioreactor & Spirochaeta psychrophila & Miyazaki et al. (2014) \\
\hline & Dilution to extinction technique & Sulfurovum aggregans & Mino et al. (2014) \\
\hline & & Thermococcus cleftensis & Hensley et al. (2014) \\
\hline & & Thermococcus paralvinellae & Hensley et al. (2014) \\
\hline & Potential controlled electrode & Brevundimonas denitrificans & Tsubouchi et al. (2014) \\
\hline & Hungate tubes & Thermococcus nautili & Gorlas et al. (2014) \\
\hline & & Crassaminicella profunda & Lakhal et al. (2015) \\
\hline & & Methanoculleus taiwanensis & Weng et al. (2015) \\
\hline
\end{tabular}

temperature and pressure requirements, may be indigenous deep-sea residents, such as Psychromonas hadalis/kaikoae, Colwellia hadaliensis/ piezophila, Shewanella benthica, and Moritella yayanosii (Table 2), whereas some piezotolerant bacteria may originate from other environments, such as spore-forming bacteria like Clostridium strains (Lauro et al., 2004) and Bacillus stearothermophillus (Bartholomew and Rittenberg, 1949).

Only a minor fraction of the microorganisms in the deep sea has been obtained in culture (Deming and Baross, 2000). On one hand, cells may be active in situ, but they can be resistant to culturing or can remain inactive (dormant) in situ due to starvation or other stresses for long periods and require recovery using particular incubation conditions. On the other hand, there are common problems inherent to culture as follows: (1) Medium: concentration and composition of organic/ inorganic constituents may be inappropriate; growth of some cells may be activated or suppressed by certain chemicals; some cells may not grow on a solidified agent. (2) Cultivation condition: physicochemical factors may be unsuitable, such as pressure, temperature and the concentration of $\mathrm{O}_{2}$; the communication among cells may be limited or destroyed. (3) Method of detection or separation: growth of some cells is very slow and/or growth may reach saturation at low cell concentrations, so that some simple, rapid and highly sensitive methods of detection or separation are required.

In this mini-review, we summarize the current knowledge of recognized piezophilic microbes (including their isolation methods), and recommend effective cultivation strategies with the aim of presenting novel insights into culturing microbes from deep-sea environments.

\section{Diverse deep-sea microbes}

The deep sea is the largest biome, and it contains more than half of the ocean's microbes (Salazar et al., 2016). By culture-independent methods, highly diverse bacteria have been found in deep-sea sediments (Schauer et al., 2010) and deep water. For example, using a massively parallel tag sequecing strategy, Sogin et al. (2006) indicated that most of the diversity was due to numerous, low-abundance populations of microbes (or so called "rare biosphere") in deep-sea water. Using high-throughput sequencing of the 16S rRNA gene, Salazar et al.
(2016) found that most abundant pelagic prokaryotes present in the deep ocean at a global scale were Gammaproteobacteria, Alphaproteobacteria, Actinobacteria, Thaumarchaeota and Deltaproteobacteria, and $\sim 50 \%$ of the operational taxonomic units (OTUs) belong to previously unknown prokaryotic taxa, most of which are rare and appear in just a few samples. In addition, the study of He and Zhang (2016) revealed that Proteobacteria, Actinobacteria, and Bacteroidetes were the predominant phyla in deep-sea hydrothermal vents.

On the other hand, many groups have made efforts to explore and culture special and diverse deep-sea microbes from various environments. Thermophile archaea and bacteria (Zeng et al., 2015b; Zhao et al., 2015) were isolated and identified from deep-sea hydrothermal vent samples (i.e. sediments, black smoker chimney, or sulfide). Grampositive piezophilic bacteria were often isolated from deep subsurface sediments (Runko et al., 2014). Polycyclic aromatic hydrocarbonoclastic bacteria were obtained from deep-sea sediments, such as the high-latitude Arctic Ocean (Dong et al., 2014) and the Middle Atlantic Ridge (Cui et al., 2008). Recently, Ciobanu et al. (2014) endeavored to cultivate microbes from $1922 \mathrm{~m}$ below the seafloor of the Canterbury Basin using methods that mimicked in situ conditions, and showed that both bacteria (belonged to Alpha-, Beta-, Gamma-proteobacteria, Actinobacteria and Armatimonadetes) and fungi (e.g., Cadophora) could be recovered from deep sediment layers. In addition, bacteria from deep-sea water have been regularly cultured and identified (Cao et al., 2014; Huo et al., 2015; Li et al., 2015). Deep-sea eukaryotes, namely, amphipods (Lauro et al., 2007), deep-sea fishes (Nakayama et al., 1994), holothurians (Deming et al., 1984) and sponges (Xin et al., 2011), also provide habitats for microbial life. Sinking particles in the benthic environment were revealed to carry abundant heterotrophic bacteria that could be cultured (Deming, 1985). Overall, microbes with various characteristics are widely distributed in almost all areas of the deep sea.

Using traditional culturing methods for surface seawater, freshwater and soil microorganisms, many researchers have obtained deep-sea microbes. However, better success has followed from the use of modified approaches or special strategies for isolating deep-sea microbes. Recently, using modified media, dilution-to-extinction techniques, or special devices, more than 40 novel deep-sea bacteria and archaea have 


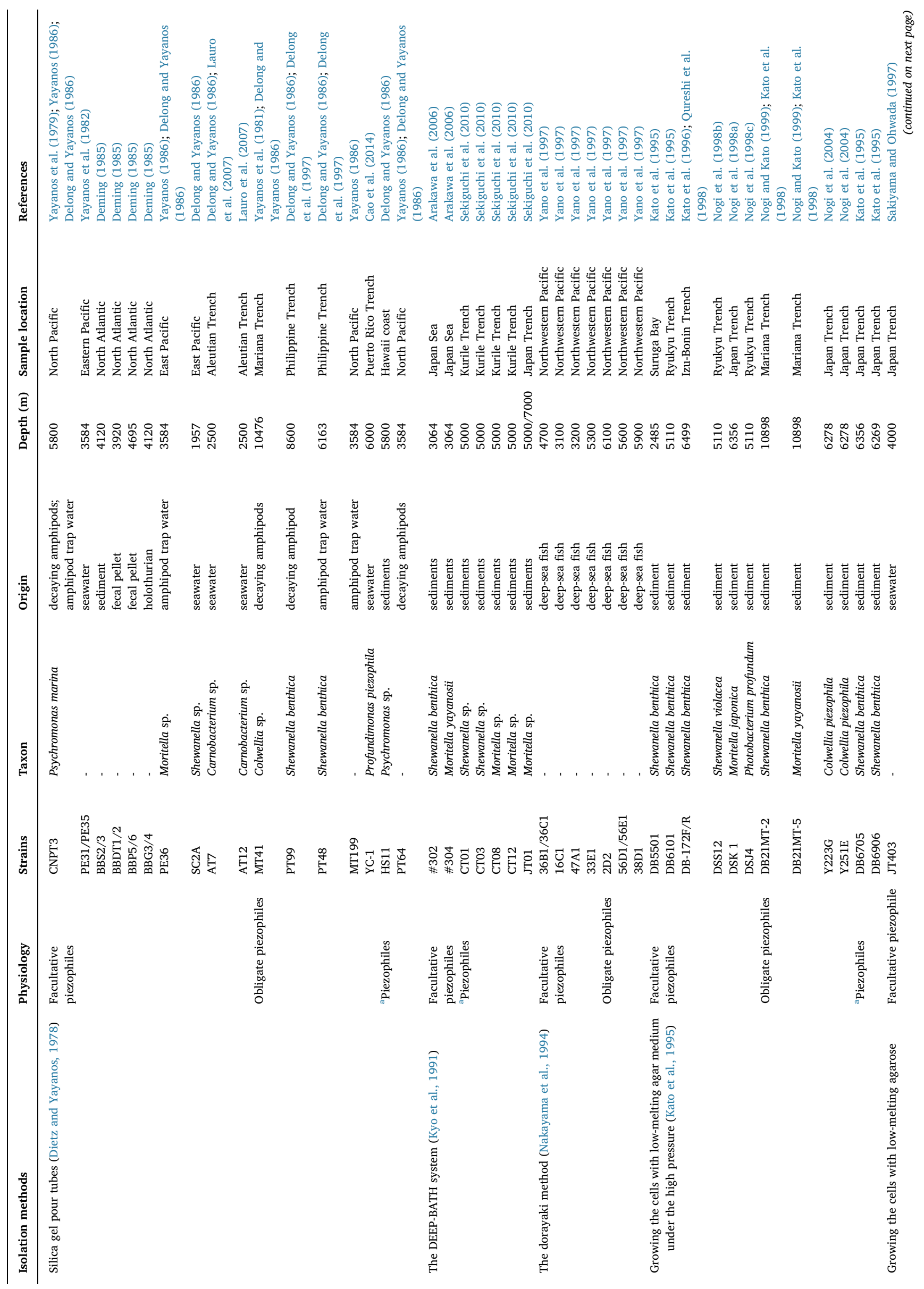




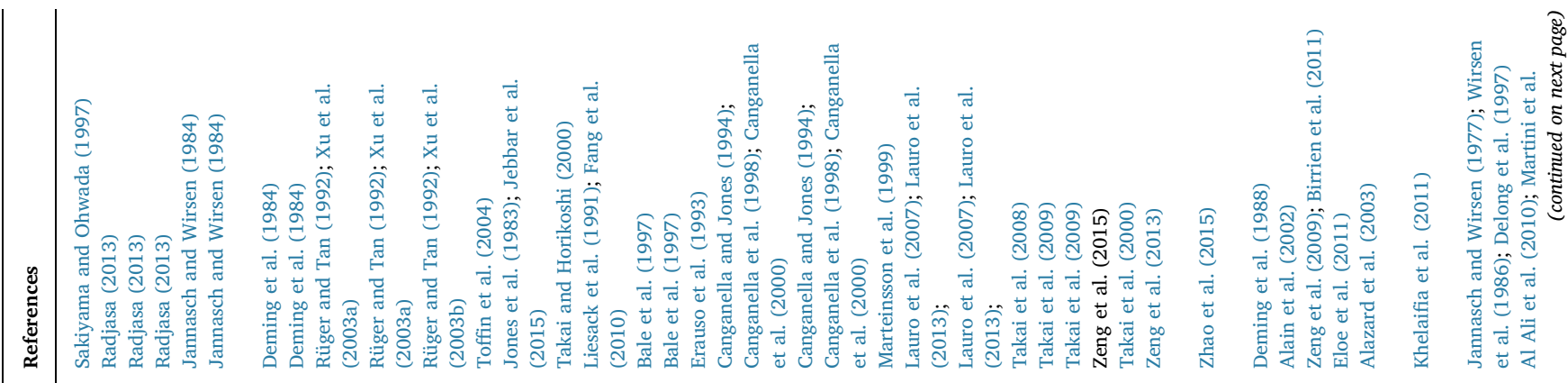

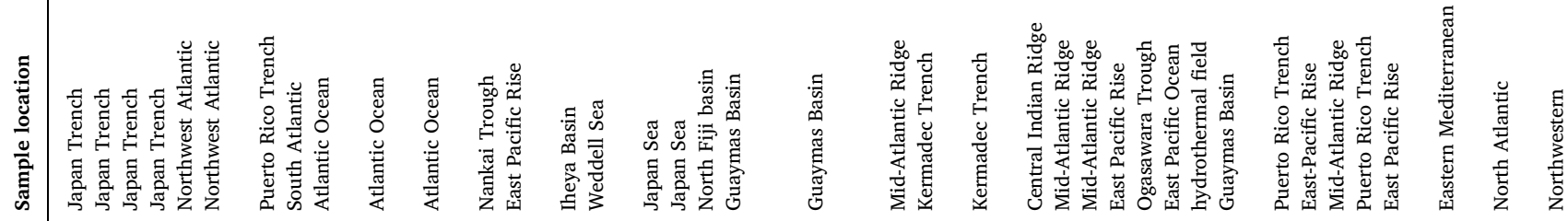
实

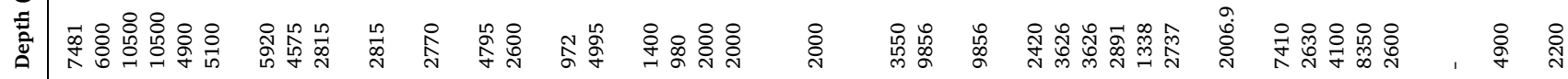
แUm

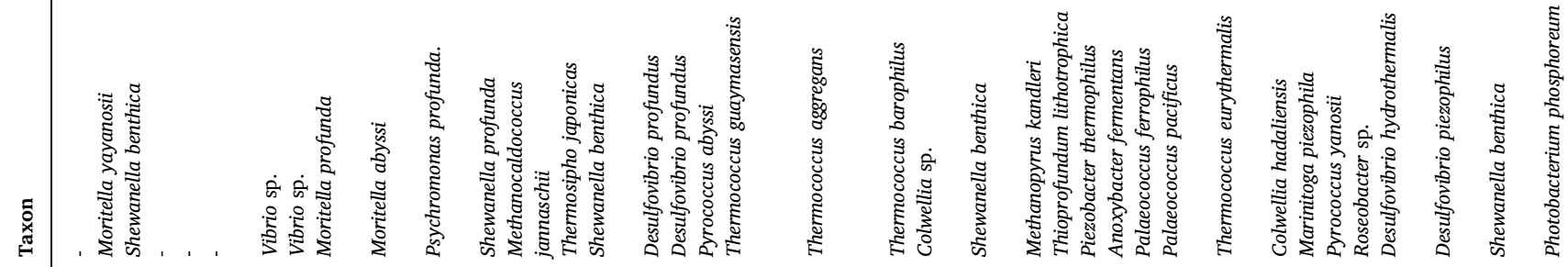

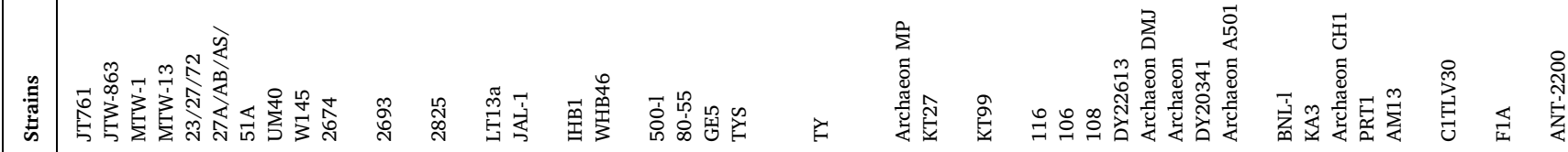

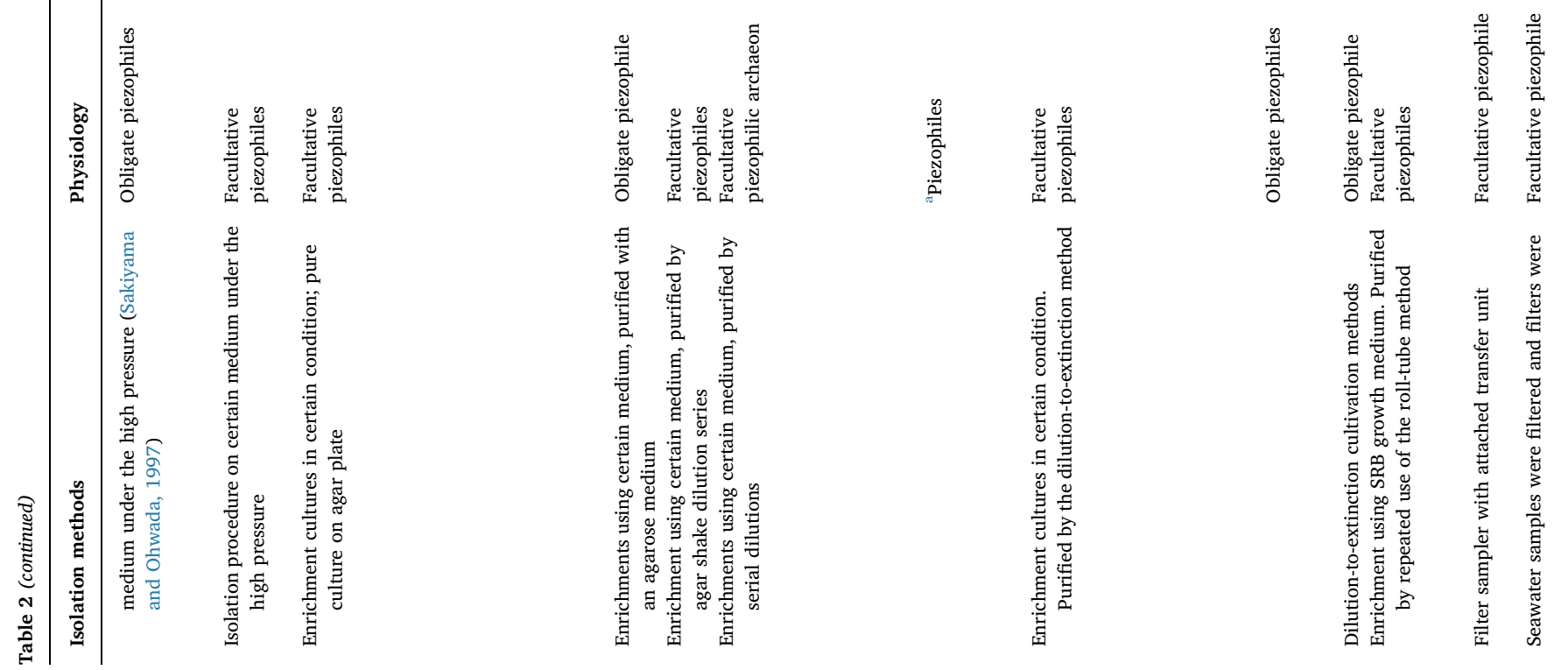


been isolated, identified and recognized; these organisms were recovered from various habitats (data for statistics were from published papers in the International Journal of Systematic and Evolutionary Microbiology). Most of these bacteria belong to phyla Actinobacteria, Proteobacteria ( $\alpha-, \beta-, \gamma-$ and $\varepsilon-$ ), Bacteroidetes, and Firmicutes. For archaea, most of the novel species belong to Euryarchaeota. A greater proportion of piezotolerant bacteria may be found than piezophilic bacteria (Table 1).

\section{Cultivation of piezophilic microbes}

Since the first obligate piezophilic bacterium (Colwellia sp. MT41) was isolated from a deep-sea decompressing amphipod in the Mariana trench (Yayanos et al., 1981), numerous deep-sea piezophilic microorganisms have been isolated from seawater, sediments and hydrothermal vents (Table 2). In general, the procedure to isolate piezophilic microbes is a combination of traditional methods and high pressure techniques; the first and most essential step is to place the cells at an in situ pressure as soon as possible after collection. In addition, elevated pressure, as a necessary condition for piezophilic growth, should be available throughout part or all of the isolation processes. Several highpressure laboratory techniques have been developed, including pressure vessels for maintaining in situ pressure, which permit the recovery and examination of colonies at high pressure. Yayanos and his group were the first to successfully isolate a piezophilic bacterium (Psychromonas marina CNPT3) using silica gel pour tubes (Dietz and Yayanos, 1978). Subsequently, many piezophilic bacteria have been cultured using this method. Later, JAMSTEC (Japan Marine Science and Technology Center) designed and developed a DEEP-BATH system (deep-sea baro-piezophile and thermophile isolation and cultivation system) for collecting, isolating and cultivating deep-sea microbes (Kyo et al., 1991), with which many valuable piezophilic bacteria have been obtained. Different approaches have also been attempted. For example, Imachi et al. (2011) cultivated the methanogenic community from subseafloor sediments using a continuous-flow bioreactor.

Overall, it seems that there is a limited diversity of cultured piezophilic bacteria (Table 2), possibly reflecting artificial selection due to the use of rich, heterotrophic growth media. Therefore, it is likely that one strategy for increasing the diversity of piezophilic bacterial isolates is to develop special growth media. A second strategy is to obtain good samples, which should be kept in the dark, at a temperature and pressure commensurating with the in situ environmental conditions.

\section{Cultivation of piezotolerant microbes}

It has been reported that piezotolerant aerobic strains were often dominant whenever attempts were made to isolate microbes from some deep-sea environments. Early research on the deep sea reported that the number of bacteria that could grow in a nutrient medium at $1 \mathrm{~atm}$ was almost as many as could grow at 700 atm; however, only a few bacteria from Indian Ocean Deeps could grow at 1000 atm (ZoBell and Morita, 1959). More recently, Takami et al. (1997) found various non-extremophilic bacteria from the Mariana Trench. Later, Parkes et al. (2009) developed the DeepIsoBUG system for enriching and isolating deep-sea microbes without depressurization, and the results showed that almost all the enriched bacteria could grow at atmospheric pressure. Similar results were also shown by Jannasch et al. (1982) with $4000 \mathrm{~m}$ deep seawater samples. These studies increased our attention to piezotolerant microbes. Recently, many deep-sea bacteria and archaea have been isolated and identified, most of which were piezotolerant (Table 1). In brief, the study of piezotolerant bacteria is as important as the study of piezophiles.

Laurent and Karine (2014) suggested that a main challenge for microbiologists studying the deep biosphere was the development of culturing strategies for currently uncultured microorganisms. Many techniques with high culture efficiency that have been developed for 
isolating bacteria from surface water, freshwater, sediments, soils and organisms will be described here, which can be developed to explore the deep-sea biosphere, especially for isolating piezotolerant microbes.

\subsection{Improving traditional cultivation methods}

Compared with common microbes, deep-sea bacteria have different growth requirements regarding nutrients and environmental factors. The information from cultured microbes provides essential knowledge about necessary growth elements for the isolation of currently uncultured bacteria, such as carbon sources, whose composition is of great importance (Uphoff et al., 2001; Alain and Querellou, 2009), but low concentration of nutrients contributes more to obtaining several conventionally-uncultured microbes. For instance, Sphingomonas alaskensis RB2256 ${ }^{\mathrm{T}}$ could only grow in a liquid seawater medium containing less than $1 \mathrm{mg} \mathrm{l}^{-1}$ of dissolved organic carbon when it was first cultivated (Vancanneyt et al., 2001). Sulfur sources are also very important. For instance, Tripp et al. (2008) indicated that 'Candidatus Pelagibacter ubique' relies exclusively on reduced sulfur compounds that originate from other plankton. In addition, cultivation temperature, $\mathrm{pH}$ and oxygen concentration should be adjusted to simulate the in situ environment of the deep-sea microbes to be isolated. Moreover, bacterial physiology and function should be considered as a guide for culturing, i.e. increasing incubation time and supplying growth-requirement molecules (signal molecules, electron acceptors or cell-free extracts) (Table 3). Some disadvantages of the plating method include the production of $\mathrm{H}_{2} \mathrm{O}_{2}$ after autoclaving; this may be controlled by supplying catalase or sodium pyruvate to degrade the $\mathrm{H}_{2} \mathrm{O}_{2}$. The enrichment method may be appropriate for the recovery of some bacteria (Fichtel et al., 2012). The end result is that many deep-sea microbes have been isolated by using improved versions of traditional cultivation methods (Table 1).

\subsection{Single cell isolation techniques}

Spreading inocula over the surface of agar plates may have drawbacks. For example, plates have limited space and nutrients, which make cells compete with one another. Fast-growing bacteria could inhibit the growth of slow growers, contributing to the "great plate count anomaly" (Staley and Konopka, 1985). Single cell sorting approaches have been developed, and show great advantages, such as overcoming the shortcomings of spread plating. Dilution-to-extinction cultivation technique is one of the most popular methods, and it can recover many novel strains. The most abundant bacterium (SAR11) in the ocean was difficult to culture, but it was isolated using this method (Rappé et al., 2002; Stingl et al., 2007; Song et al., 2009). Another example involves the recovery and cultivation of sulfate-reducing bacteria (Colin et al., 2013). Micromanipulation is another important technology that was used in detecting and separating single microbial cells (Fröhlich and König, 2000; Ashida et al., 2010). More recently, flow cytometry has been used, and it has enabled several thousands of single cells to be cultured. Moreover, Slava Epstein (a microbiologist at Northeastern University in Boston, USA) and his group developed and used Ichip (or minitrap) for the high-throughput in situ cultivation of "uncultivable" microbial species (Nichols et al., 2010; Sizova et al., 2012). Additionally, Ma et al. (2014) designed a microfluidics-based workflow for genetically targeted isolation and cultivation of microorganisms from complex clinical samples. Many more single cell isolation techniques have been reported, some of which have been used to explore the deep sea, as testified by the isolation of strain PRT1 using dilution-to-extinction method (Eloe et al., 2011).

\subsection{Coculture}

Many researchers are focused on communication among bacteria. Traditional methods have the disadvantage of selectivity, and single cell sorting approaches limit the inter-communication of bacteria. It is known that some bacteria need the existence of other bacteria to grow. A simple, modified process was developed to culture previously uncultured bacteria in the presence of cultured organisms from the same environment. Using this approach, D'Onofrio et al. (2010) recovered previously uncultured isolates from marine sediment biofilm grown on a Petri dish. There is a classic case in which autotrophic ammoniaoxidizing archaea from marine sediments were successfully enriched and cultivated in coculture with sulfur-oxidizing bacteria (Park et al., 2010). Culturing all bacteria together in an in situ environment is another coculture method. For example, a diffusion growth chamber (DGC) was developed to provide a settled place where all the strains could be kept. The chamber can be placed in a simulated in situ environment (Kaeberlein et al., 2002; Bollmann et al., 2007, 2010). A hollow-fiber membrane chamber (HFMC), which is a modified DGC chamber, was developed as an in situ cultivation device for environmental microorganisms (Aoi et al., 2009). Moreover, DGC can be successfully applied in living marine organisms, such as sponges (Steinert et al., 2014).

\subsection{Combination of different techniques}

It is well known that any one method cannot culture all types of microorganisms. Success can be improved if different methods are combined. Zengler et al. (2002) developed the combination of gel microdrop (GMD) technique and flow cytometry method (FCM) to

Table 3

Improved traditional cultivation methods.

\begin{tabular}{|c|c|c|}
\hline Methods & Results & Ref. \\
\hline \multirow[t]{2}{*}{ Add organic sources } & Yielding higher number and more diverse isolates & Uphoff et al. (2001) \\
\hline & Increasing the concentration of fastidious bacteria & Tripp et al. (2008) \\
\hline Oligo-culture & Obtaining conventionally-uncultured species & Vancanneyt et al. (2001) \\
\hline \multirow[t]{3}{*}{ Increase incubation times } & Cultivation and detection of previously uncultured microbe & Stevenson et al. (2004) \\
\hline & Allowing the development of visible colonies of members of rarely isolated groups & Davis et al. (2005) \\
\hline & Isolating previously uncultured species & Stott et al. (2008) \\
\hline \multirow{2}{*}{ Supply signal molecules } & High cultivation efficiencies & Bruns et al. (2002) \\
\hline & Inducing an "uncultivable" microorganism to grow in vitro & Nichols et al. (2008) \\
\hline \multirow[t]{2}{*}{ Use electron acceptors } & Recovering previously uncultured hyperthermophiles & Kashefi et al. (2002) \\
\hline & High cultivation efficiencies & Kopke et al. (2005) \\
\hline \multirow[t]{2}{*}{ Add catalase or sodium pyruvate } & Resuscitating viable but nonculturable cells & Mizunoe et al. (2000) \\
\hline & Improving recoverability of microbial colonies & Olson et al. (2000) \\
\hline Add cell-free extract & Isolating uncultivable anaerobic thermophiles & Kim et al. (2008) \\
\hline \multirow[t]{2}{*}{ Use of other gelling reagents } & Increasing culturability & Tamaki et al. (2005) \\
\hline & Isolating previously uncultured species & Stott et al. (2008) \\
\hline Adhesion to solid surfaces & Enriching previously uncultured bacteria & Gich et al. (2012) \\
\hline
\end{tabular}


Table 4

The applications of GMD and FCM techniques.

\begin{tabular}{|c|c|c|c|c|c|}
\hline Samples & Encapsulation method & Cultivation & Media & Aim & Ref. \\
\hline Seawater & $\begin{array}{l}\text { Agarose; } \\
\text { Glass membrane filter }\end{array}$ & Chromatography columns & Filtered seawater alone & High throughput culture & Ji et al. (2011) \\
\hline Strain & $\begin{array}{l}\text { Agarose; } \\
\text { CellSys } 100 \text { microdrop maker }\end{array}$ & Test tubes/ flasks & Artificial seawater-based medium & Enrichment of non-growing bacteria & Akselband et al. (2006) \\
\hline Seawater & $\begin{array}{l}\text { Agarose; } \\
\text { CellSys } 100 \text { microdrop maker }\end{array}$ & Chromatography columns & Filtered seawater alone & High throughput culture & Zengler et al. (2002) \\
\hline Soil & $\begin{array}{l}\text { Agarose; } \\
\text { CellSys } 100 \text { microdrop maker }\end{array}$ & Chromatography columns & Diluted soil extract & High throughput culture & Zengler et al. (2002) \\
\hline Strain & $\begin{array}{l}\text { Agarose; } \\
\text { Glass membrane filter }\end{array}$ & Test tubes/flasks & Thiamin-free synthetic medium & Enrichment of non-growing bacteria & Manome et al. (2001) \\
\hline Strain & $\begin{array}{l}\text { Agarose; } \\
\text { CellSys } 100 \text { microdrop maker }\end{array}$ & Test tubes/ flasks & Synthetic dextrose medium & Enrichment of non-growing bacteria & Gift et al. (1996) \\
\hline
\end{tabular}

selectively enrich non-growing bacterial cells in an artificial model system. This technique combines the encapsulation of cells in gel microdroplets for massively parallel microbial cultivation under low nutrient flux conditions, followed by flow cytometry to detect microdroplets containing microcolonies. Under these conditions, single encapsulated cells grow and form microcolonies within the microcapsules. Flow cytometry has been used as a sensitive tool to detect growth within the microcapsules (Zengler et al., 2005). Methods have been developed to enrich mixed bacterial populations for slow-growing microorganisms using GMD combined with fluorochrome staining and flow cytometry (Table 4). Our group has used GMD method to culture the "uncultured" microbes from surface seawater (Ji et al., 2011) and has also attempted to obtain diverse bacteria from deep-sea samples (Zhang et al., unpublished). In our results, over $82 \%$ of the strains using the GMD method were not obtained by a plating method from a hydrothermal sediment at the Okinawa Trough, and $50 \%$ of the genera belonged to the class $\alpha$-proteobacteria which was present at a very low relative abundance $(0.93 \%)$ in the sample. In addition, over $44 \%$ of the strains from the GMD method were not obtained from a plating method for the polymetallic nodule area. In this case, $50 \%$ of the genera belonged to the phylum Actinobacteria, which was present at a very low relative abundance $(1.04 \%)$ in the sample.

\section{Perspectives}

Although considerable progress has been made, due to the complexity of the deep-sea environment, microbes remain mysterious. The journey to explore the deep-sea world still faces enormous challenges. Four suggestions are made for the future. First, advanced deep-sea exploring devices, such as deep-water robots, deep-sea sampling and detecting equipment, should be further designed and produced. Second, special materials (organic or inorganic) that can remain stable in deepsea conditions should be further developed. For example, new encapsulation materials would improve the application of GMD technique for culturing deep-sea bacteria under in situ conditions. Third, highly sensitive observation and detection technologies (such as fluorescence microscopy technology, flow cytometry technology, microbial staining technology, and other advanced methods) should be more widely developed and applied in culturing and separating microbes. Fourth, culture-independent technology (such as metagenomics, metatranscriptomics, and single-cell sequencing) remains essential for obtaining more information on uncultured microbes. It is also highly important to establish a connection between microbial growth requirements and sequence data, though this is difficult.

In the omics age today, cultivation of microbes is still necessary, as cultivation can contribute to comprehensively understanding the detailed physiology of microbes and the complex environmental processes associated with them. In addition, cultures can provide complete genomes and the means to verify potential metabolic ability or ecosystem function of microbes which have been predicted on the basis of genomics data, for example, which organic substrates are utilized, what compounds are produced, or how metabolic reactions are performed. Moreover, cultivation is the first step for the microbes to be applied on environmental remediation, energy and pharmaceutical industry. In summary, the deep-sea remains a mystery, but cultivation of more deep-sea microbes may be a breakthrough for exploring the deep sea, and any attempt to create and develop cultivation methods would be worthwhile.

\section{Acknowledgements}

This work was supported by projects from the Major State Basic Research Development Program of China (2013CB429700) and the Scientific and Technological Innovation Project of Qingdao National Laboratory for Marine Science and Technology (No.2016ASKJ14 )

\section{References}

Akselband, Y., Cabral, C., Castor, T.P., Chikarmane, H.M., McGrath, P., 2006. Enrichment of slow-growing marine microorganisms from mixed cultures using gel microdrop (GMD) growth assay and fluorescence-activated cell sorting. J. Exp. Mar. Biol. Ecol. 329, 196-205. http://dx.doi.org/10.1016/j.jembe.2005.08.018.

Al Ali, B., Garel, M., Cuny, P., Miquel, J.-C., Toubal, T., Robert, A., Tamburini, C., 2010. Luminous bacteria in the deep-sea waters near the ANTARES underwater neutrino telescope (Mediterranean Sea). Chem. Ecol. 26, 57-72. http://dx.doi.org/10.1080/ 02757540903513766.

Alain, K., Marteinsson, V.T., Miroshnichenko, M.L., Bonch-Osmolovskaya, E.A., Prieur, D., Birrien, J.-L., 2002. Marinitoga piezophila sp. nov., a rod-shaped, thermo-piezophilic bacterium isolated under high hydrostatic pressure from a deep-sea hydrothermal vent. Int. J. Syst. Evol. Microbiol. 52, 1331-1339. http://dx.doi.org/10. 1099/00207713-52-4-1331.

Alain, K., Querellou, J., 2009. Cultivating the uncultured: limits, advances and future challenges. Extremophiles 13, 583-594. http://dx.doi.org/10.1007/s00792-0090261-3.

Alazard, D., Dukan, S., Urios, A., Verhé, F., Bouabida, N., Morel, F., Thomas, P., Garcia, J. L., Ollivier, B., 2003. Desulfovibrio hydrothermalis sp. nov., a novel sulfate-reducing bacterium isolated from hydrothermal vents. Int. J. Syst. Evol. Microbiol. 53, 173-178. http://dx.doi.org/10.1099/ijs.0.02323-0.

Aoi, Y., Kinoshita, T., Hata, T., Ohta, H., Obokata, H., Tsuneda, S., 2009. Hollow-fiber membrane chamber as a device for in situ environmental cultivation. Appl. Environ. Microbiol. 75, 3826-3833. http://dx.doi.org/10.1128/AEM.02542-08.

Arakawa, S., Nogi, Y., Sato, T., Yoshida, Y., Usami, R., Kato, C., 2006. Diversity of piezophilic microorganisms in the closed ocean Japan Sea. Biosci. Biotechnol. Biochem. 70, 749-752. http://dx.doi.org/10.1271/bbb.70.749.

Ashida, N., Ishii, S., Hayano, S., Tago, K., Tsuji, T., Yoshimura, Y., Otsuka, S., Senoo, K. 2010. Isolation of functional single cells from environments using a micromanipulator: application to study denitrifying bacteria. Appl. Microbiol. Biotechnol. 85, 1211-1217. http://dx.doi.org/10.1007/s00253-009-2330-z.

Bale, S.J., Goodman, K., Rochelle, P.A., Marchesi, J.R., Fry, J.C., Weightman, A.J., Parkes, R.J., 1997. Desulfovibrio profundus sp. nov., a novel barophilic sulfate-reducing bacterium from deep sediment layers in the Japan Sea. Int. J. Syst. Bacteriol. 47, 515-521. http://dx.doi.org/10.1099/00207713-47-2-515.

Bartholomew, J.W., Rittenberg, S.C., 1949. Thermophilic bacteria from deep ocean bottom cores. J. Bacteriol. 57, 658 (658).

Bercovici, S.K., Hansell, D.A., 2016. Dissolved organic carbon in the deep Southern Ocean: local versus distant controls. Glob. Biogeochem. Cycles 30, 350-360. http:// dx.doi.org/10.1002/2015GB005252.

Birrien, J.-L., Zeng, X., Jebbar, M., Cambon-Bonavita, M.-A., Quérellou, J., Oger, P., Bienvenu, N., Xiao, X., Prieur, D., 2011. Pyrococcus yayanosii sp. nov., an obligate piezophilic hyperthermophilic archaeon isolated from a deep-sea hydrothermal vent. 
Int. J. Syst. Evol. Microbiol. 61, 2827-2831. http://dx.doi.org/10.1099/ijs.0. 024653-0.

Bollmann, A., Lewis, K., Epstein, S.S., 2007. Incubation of environmental samples in a diffusion chamber increases the diversity of recovered isolates. Appl. Environ. Microbiol. 73, 6386-6390. http://dx.doi.org/10.1128/AEM.01309-07.

Bollmann, A., Palumbo, A.V., Lewis, K., Epstein, S.S., 2010. Isolation and physiology of bacteria from contaminated subsurface sediments. Appl. Environ. Microbiol. 76, 7413-7419. http://dx.doi.org/10.1128/AEM.00376-10.

Bruns, A., Cypionka, H., Overmann, J., 2002. Cyclic AMP and acyl homoserine lactones increase the cultivation efficiency of heterotrophic bacteria from the central Baltic Sea. Appl. Environ. Microbiol. 68, 3978-3987. http://dx.doi.org/10.1128/AEM.68.8. 3978-3987.2002.

Cai, W.-J., Reimers, C.E., 1995. Benthic oxygen flux, bottom water oxygen concentration and core top organic carbon content in the deep northeast Pacific Ocean. Deep-Sea Res. I 42, 1681-1699. http://dx.doi.org/10.1016/0967-0637(95)00073-F.

Canganella, F., Gambacorta, A., Kato, C., Horikoshi, K., 2000. Effects of hydrostatic pressure and temperature on physiological traits of Thermococcus guaymasensis and Thermococcus aggregans growing on starch. Microbiol. Res. 154, 297-306. http://dx. doi.org/10.1016/S0944-5013(00)80003-8.

Canganella, F., Gonzalez, J.M., Yanagibayashi, M., Kato, C., Horikoshi, K., 1997. Pressure and temperature effects on growth and viability of the hyperthermophilic archaeon Thermococcus peptonophilus. Arch. Microbiol. 168, 1-7. http://dx.doi.org/10.1007/ s002030050462.

Canganella, F., Jones, W.J., 1994. Microbial characterization of thermophilic archaea isolated from the Guaymas Basin hydrothermal vent. Curr. Microbiol. 28, 299-306. http://dx.doi.org/10.1007/BF01573210.

Canganella, F., Jones, W.J., Gambacorta, A., Antranikian, G., 1998. Thermococcus guaymasensis sp. nov. and Thermococcus aggregans sp. nov., two novel thermophilic archaea isolated from the Guaymas Basin hydrothermal vent site. Int. J. Syst. Bacteriol. 48, 1181-1185. http://dx.doi.org/10.1099/00207713-48-4-1181.

Cao, Y., Chastain, R.A., Eloe, E.A., Nogi, Y., Kato, C., Bartlett, D.H., 2014. Novel psychropiezophilic Oceanospirillales species Profundimonas piezophila gen. nov., sp. nov. isolated from the deep-sea environment of the Puerto Rico trench. Appl. Environ. Microbiol. 80, 54-60. http://dx.doi.org/10.1128/AEM.02288-13.

Choi, A., Song, J., Joung, Y., Kogure, K., Cho, J.-C., 2015. Lentisphaera profundi sp. nov., isolated from deep-sea water. Int. J. Syst. Evol. Microbiol. 65, 4186-4190. http://dx. doi.org/10.1099/ijsem.0.000556.

Ciobanu, M.-C., Burgaud, G., Dufresne, A., Breuker, A., Rédou, V., Maamar, S.B., Gaboyer, F., Vandenabeele-Trambouze, O., Lipp, J.S., Schippers, A., Vandenkoornhuyse, P., Barbier, G., Jebbar, M., Godfroy, A., Alain, K., 2014. Microorganisms persist at record depths in the subseafloor of the Canterbury Basin. ISME J. 8, 1370-1380. http://dx. doi.org/10.1038/ismej.2013.250.

Colin, Y., Goñi-Urriza, M., Caumette, P., Guyoneaud, R., 2013. Combination of high throughput cultivation and $d s r$ A sequencing for assessment of sulfate-reducing bacteria diversity in sediments. FEMS Microbiol. Ecol. 83, 26-37. http://dx.doi.org/10. 1111/j.1574-6941.2012.01452.x.

Cui, Z., Lai, Q., Dong, C., Shao, Z., 2008. Biodiversity of polycyclic aromatic hydrocarbondegrading bacteria from deep sea sediments of the Middle Atlantic Ridge. Environ. Microbiol. 10, 2138-2149. http://dx.doi.org/10.1111/j.1462-2920.2008.01637.x.

Dai, X., Shi, X., Gao, X., Liang, J., Zhang, X.-H., 2015. Salipiger nanhaiensis sp. nov., a bacterium isolated from deep sea water. Int. J. Syst. Evol. Microbiol. 65, 1122-1126. http://dx.doi.org/10.1099/ijs.0.000066.

Dai, X., Shi, X., Gao, X., Liu, J., Zhang, X.-H., 2014. Roseivivax marinus sp. nov., isolated from deep water. Int. J. Syst. Evol. Microbiol. 64, 2540-2544. http://dx.doi.org/10. 1099/ijs.0.062760-0.

Davis, K.E.R., Joseph, S.J., Janssen, P.H., 2005. Effects of growth medium, inoculum size, and incubation time on culturability and isolation of soil bacteria. Appl. Environ. Microbiol. 71, 826-834. http://dx.doi.org/10.1128/AEM.71.2.826-834.2005.

Delong, E.F., Franks, D.G., Yayanos, A.A., 1997. Evolutionary relationships of cultivated psychrophilic and barophilic deep-sea bacteria. Appl. Environ. Microbiol. 63, 2105-2108.

DeLong, E.F., Preston, C.M., Mincer, T., Rich, V., Hallam, S.J., Frigaard, N.-U., Martinez, A., Sullivan, M.B., Edwards, R., Brito, B.R., Chisholm, S.W., Karl, D.M., 2006. Community genomics among stratified microbial assemblages in the ocean's interior. Science 311, 496-503. http://dx.doi.org/10.1126/science.1120250.

Delong, E.F., Yayanos, A.A., 1986. Biochemical function and ecological significance of novel bacterial lipids in deep-sea procaryotes. Appl. Environ. Microbiol. 51, 730-737.

Deming, J.W., 1985. Bacterial growth in deep-sea sediment trap and boxcore samples. Mar. Ecol. Prog. Ser. 25, 305-312.

Deming, J.W., Baross, J.A., 2000. Survival, dormancy, and nonculturable cells in extreme deep-sea environments. In: Colwell, R.R., Grimes, D.J. (Eds.), Nonculturahle Microorganisms in the Environment. Springer, US, Washington, DC, pp. 147-197. http://dx.doi.org/10.1007/978-1-4757-0271-2 10.

Deming, J.W., Hada, H., Colwell, R.R., Luehrsen, K.R., Fox, G.E., 1984. The ribonucleotide sequence of 5S rRNA from two strains of deep-sea barophilic bacteria. J. Gen. Microbiol. 130, 1911-1920. http://dx.doi.org/10.1099/00221287-130-8-1911.

Deming, J.W., Somers, L.K., Straube, W.L., Swartz, D.G., Macdonell, M.T., 1988. Isolation of an obligately barophilic bacterium and description of a new genus, Colwellia gen. nov. Syst. Appl. Microbiol. 10, 152-160. http://dx.doi.org/10.1016/S0723-2020(88) 80030-4.

D'Hondt, S., Inagaki, F., Zarikian, C.A., Abrams, L.J., Dubois, N., Engelhardt, T., Evans, H., Ferdelman, T., Gribsholt, B., Harris, R.N., Hoppie, B.W., Hyun, J.-H., Kallmeyer, J., Kim, J., Lynch, J.E., McKinley, C.C., Mitsunobu, S., Morono, Y., Murray, R.W., Pockalny, R., Sauvage, J., Shimono, T., Shiraishi, F., Smith, D.C., Smith-Duque, C.E., Spivack, A.J., Steinsbu, B.O., Suzuki, Y., Szpak, M., Toffin, L., Uramoto, G., Yamaguchi, Y.T., Zhang, G.-1., Zhang, X.-H., Ziebis, W., 2015. Presence of oxygen and aerobic communities from sea floor to basement in deep-sea sediments. Nat. Geosci. 8, 299-304. http://dx.doi.org/10.1038/ngeo2387.

Dietz, A.S., Yayanos, A.A., 1978. Silica gel media for isolating and studying bacteria under hydrostatic pressure. Appl. Environ. Microbiol. 36, 966-968.

Dong, C., Bai, X., Sheng, H., Jiao, L., Zhou, H., Shao, Z., 2014. Distribution of PAHs and the PAH-degrading bacteria in the deep-sea sediments of the high-latitude Arctic Ocean. Biogeosciences 11, 13985-14021. http://dx.doi.org/10.5194/bg-12-21632015.

D'Onofrio, A., Crawford, J.M., Stewart, E.J., Witt, K., Gavrish, E., Epstein, S., Clardy, J., Lewis, K., 2010. Siderophores from neighboring organisms promote the growth of uncultured bacteria. Chem. Biol. 17, 254-264. http://dx.doi.org/10.1016/j. chembiol.2010.02.010.

Eloe, E.A., Malfatti, F., Gutierrez, J., Hardy, K., Schmidt, W.E., Pogliano, K., Pogliano, J., Azam, F., Bartlett, D.H., 2011. Isolation and characterization of a psychropiezophilic alphaproteobacterium. Appl. Environ. Microbiol. 77, 8145-8153. http://dx.doi.org/ 10.1007/BF00252219.

Erauso, G., Reysenbach, A.-L., Godfroy, A., Meunier, J.-R., Crump, B., Partensky, F., Baross, J.A., Marteinsson, V., Barbier, G., Pace, N.R., Prieur, D., 1993. Pyrococcus abyssi sp. nov., a new hyperthermophilic archaeon isolated from a deep-sea hydrothermal vent. Arch. Microbiol. 160, 338-349.

Fan, X., Qiao, Y., Gao, X., Zhang, X.-H., 2014a. Nocardioides pacificus sp. nov., isolated from deep sub-seafloor sediment. Int. J. Syst. Evol. Microbiol. 64, 2217-2222. http:// dx.doi.org/10.1099/ijs.0.059873-0.

Fan, X., Yu, T., Li, Z., Zhang, X.-H., 2014b. Luteimonas abyssi sp. nov., isolated from deepsea sediment. Int. J. Syst. Evol. Microbiol. 64, 668-674. http://dx.doi.org/10.1099/ ijs.0.056010-0

Fan, X., Zhang, Z., Li, Z., Zhang, X.-H., 2014c. Luteococcus sediminum sp. nov., isolated from deep subseafloor sediment of the South Pacific Gyre. Int. J. Syst. Evol. Microbiol. 64, 2522-2527. http://dx.doi.org/10.1099/ijs.0.058529-0.

Fang, J., Bazylinski, D.A., 2008. Deep-sea geomicrobiology and biogeochemistry. In: Michiels, C., Bartlett, D.H., Aertsen, A. (Eds.), High-Pressure Microbiology. ASM Press, Washington, DC, USA, pp. 237-264.

Fang, J., Zhang, L., Bazylinski, D.A., 2010. Deep-sea piezosphere and piezophiles: geomicrobiology and biogeochemistry. Trends Microbiol. 18, 413-422. http://dx.doi. org $/ 10.1016 /$ j.tim.2010.06.006.

Fichtel, K., Mathes, F., Könneke, M., Cypionka, H., Engelen, B., 2012. Isolation of sulfatereducing bacteria from sediments above the deep-subseafloor aquifer. Front. Microbiol. 3, 65. http://dx.doi.org/10.3389/fmicb.2012.00065.

França, L., Albuquerque, L., da Costa, M.S., 2015. Cavicella subterranea gen. nov., sp. nov., isolated from a deep mineral-water aquifer, and emended description of the species Perlucidibaca piscinae. Int. J. Syst. Evol. Microbiol. 65, 3812-3817. http://dx.doi.org/ 10.1099/ijsem.0.000493.

Fröhlich, J., König, H., 2000. New techniques for isolation of single prokaryotic cells. FEMS Microbiol. Rev. 24, 567-572. http://dx.doi.org/10.1111/j.1574-6976.2000. tb00558.x.

Gich, F., Janys, M.A., König, M., Overmann, J., 2012. Enrichment of previously uncultured bacteria from natural complex communities by adhesion to solid surfaces. Environ. Microbiol. 14, 2984-2997. http://dx.doi.org/10.1111/j.1462-2920.2012. 02868.x.

Gift, E.A., Park, H.J., Paradis, G.A., Demain, A.L., Weaver, J.C., 1996. FACS-based isolation of slowly growing cells: double encapsulation of yeast in gel microdrops. Nat. Biotechnol. 14, 884-887. http://dx.doi.org/10.1038/nbt0796-884.

González, J.M., Kato, C., Horikoshi, K., 1995. Thermococcus peptonophilus sp. nov., a fastgrowing, extremely thermophilic archaebacterium isolated from deep-sea hydrothermal vents. Arch. Microbiol. 164, 159-164. http://dx.doi.org/10.1007/ BF02529966.

Gorlas, A., Croce, O., Oberto, J., Gauliard, E., Forterre, P., Marguet, E., 2014 Thermococcus nautili sp. nov., a hyperthermophilic archaeon isolated from a hydrothermal deep-sea vent. Int. J. Syst. Evol. Microbiol. 64, 1802-1810. http://dx.doi. org /10.1099/ijs.0.060376-0.

He, T., Zhang, X., 2016. Characterization of bacterial communities in deep-sea hydrothermal vents from three oceanic regions. Mar. Biotechnol. 18, 232-241. http://dx. doi.org/10.1007/s10126-015-9683-3.

Hensley, S.A., Jung, J.-H., Park, C.-S., Holden, J.F., 2014. Thermococcus paralvinellae sp. nov. and Thermococcus cleftensis sp. nov. of hyperthermophilic heterotrophs from deep-sea hydrothermal vents. Int. J. Syst. Evol. Microbiol. 64, 3655-3659. http://dx doi.org/10.1099/ijs.0.066100-0.

Huo, Y.-Y., You, H., Li, Z.-Y., Wang, C.-S., Xu, X.-W., 2015. Novosphingobium marinum sp. nov., isolated from seawater. Int. J. Syst. Evol. Microbiol. 65, 676-680. http://dx.doi. org/10.1099/ijs.0.070433-0.

Imachi, H., Aoi, K., Tasumi, E., Saito, Y., Yamanaka, Y., Saito, Y., Yamaguchi, T., Tomaru, H., Takeuchi, R., Morono, Y., Inagaki, F., Takai, K., 2011. Cultivation of methanogenic community from subseafloor sediments using a continuous-flow bioreactor. ISME J. 5, 1913-1925. http://dx.doi.org/10.1038/ismej.2011.64.

Jannasch, H.W., Wirsen, C.O., 1977. Retrieval of concentrated and undecompressed microbial populations from the deep sea. Appl. Environ. Microbiol. 33, 642-646.

Jannasch, H.W., Wirsen, C.O., 1984. Variability of pressure adaptation in deep sea bacteria. Arch. Microbiol. 139, 281-288. http://dx.doi.org/10.1007/BF00408367.

Jannasch, H.W., Wirsen, C.O., Taylor, C.D., 1982. Deep-sea bacteria: isolation in the absence of decompression. Science 216, 1315-1317. http://dx.doi.org/10.1126/ science. 216.4552.1315.

Jebbar, M., Franzetti, B., Girard, E., Oger, P., 2015. Microbial diversity and adaptation to high hydrostatic pressure in deep-sea hydrothermal vents prokaryotes. Extremophiles 19, 721-740. http://dx.doi.org/10.1007/s00792-015-0760-3.

Ji, S., Zhao, R., Yin, Q., Zhao, Y., Liu, C., Xiao, T., Zhang, X., 2011. Gel microbead cultivation with a subenrichment procedure can yield better bacterial cultivability from 
a seawater sample than standard plating method. J. Ocean Univ. China 11, 45-51. http://dx.doi.org/10.1007/s11802-012-1869-y.

Jones, W.J., Leigh, J.A., Mayer, F., Woese, C.R., Wolfe, R.S., 1983. Methanococcus jannaschii sp. nov., an extremely thermophilic methanogen from a submarine hydrothermal vent. Arch. Microbiol. 136, 254-261. http://dx.doi.org/10.1007/ BF00425213.

Kaeberlein, T., Lewis, K., Epstein, S.S., 2002. Isolating "uncultivable" microorganisms in pure culture in a simulated natural environment. Science 296, 1127-1129. http://dx. doi.org/10.1126/science.1070633.

Kashefi, K., Holmes, D.E., Reysenbach, A.-L., Lovley, D.R., 2002. Use of Fe(III) as an electron acceptor to recover previously uncultured hyperthermophiles: isolation and characterization of Geothermobacterium ferrireducens gen. nov., sp. nov. Appl. Environ. Microbiol. 68, 1735-1742. http://dx.doi.org/10.1128/AEM.68.4.17351742.2002

Kato, C., Li, L., Nogi, Y., Nakamura, Y., Tamaoka, J., Horikoshi, K., 1998. Extremely barophilic bacteria isolated from the Mariana Trench, challenger deep, at a depth of 11,000 meters. Appl. Environ. Microbiol. 64, 1510-1513.

Kato, C., Masui, N., Horikoshi, K., 1996. Properties of obligately barophilic bacteria isolated from a sample of deep-sea sediment from the Izu-Bonin trench. J. Mar. Biotechnol. 4, 96-99.

Kato, C., Sato, T., Horikoshi, K., 1995. Isolation and properties of barophilic and barotolerant bacteria from deep-sea mud samples. Biodivers. Conserv. 4, 1-9. http://dx. doi.org/10.1007/BF00115311.

Khelaifia, S., Fardeau, M.-L., Pradel, N., Aussignargues, C., Garel, M., Tamburini, C., Cayol, J.-L., Gaudron, S., Gaill, F., Ollivier, B., 2011. Desulfovibrio piezophilus sp. nov., a piezophilic, sulfate-reducing bacterium isolated from wood falls in the Mediterranean Sea. Int. J. Syst. Evol. Microbiol. 61, 2706-2711. http://dx.doi.org/ 10.1099/ijs.0.028670-0.

Kim, J.-J., Kim, H.-N., Masui, R., Kuramitsu, S., Seo, J.-H., Kim, K., Sung, M.-H., 2008. Isolation of uncultivable anaerobic thermophiles of the family Clostridiaceae requiring growth-supporting factors. J. Microbiol. Biotechnol. 18, 611-615.

Kopke, B., Wilms, R., Engelen, B., Cypionka, H., Sass, H., 2005. Microbial diversity in coastal subsurface sediments: a cultivation approach using various electron acceptors and substrate gradients. Appl. Environ. Microbiol. 71, 7819-7830. http://dx.doi.org/ 10.1128/AEM.71.12.7819-7830.2005.

Kyo, M., Tuji, Y., Usui, H., Itoh, T., 1991. Collection, isolation and cultivation system for deep-sea microbes study: concept and design. Ocean Technologies and Opportunities in the Pacific for the 90's. In: Proceedings of the IEEE, pp. 419-423. http://dx.doi. org/10.1109/OCEANS.1991.613968.

Lai, Q., Cao, J., Yuan, J., Li, F., Shao, Z., 2014. Celeribacter indicus sp. nov., a polycyclic aromatic hydrocarbon-degrading bacterium from deep-sea sediment and reclassification of Huaishuia halophila as Celeribacter halophilus comb. nov. Int. J. Syst. Evol. Microbiol. 64, 4160-4167. http://dx.doi.org/10.1099/ijs.0.069039-0.

Lakhal, R., Pradel, N., Postec, A., Ollivier, B., Cayol, J.-L., Godfroy, A., Fardeau, M.-L., Galés, G., 2015. Crassaminicella profunda gen. nov., sp. nov., an anaerobic marine bacterium isolated from deep-sea sediments. Int. J. Syst. Evol. Microbiol. 65 , 3097-3102. http://dx.doi.org/10.1099/ijsem.0.000386.

Laurent, T., Karine, A., 2014. Technological state of the art and challenges. In: Kallmeyers, J., Wagner, D. (Eds.), Microbial Life of the Deep Biosphere. De Gruyter, Boston, pp. 83-99.

Lauro, F.M., Bertoloni, G., Obraztsova, A., Kato, C., Tebo, B.M., Bartlett, D.H., 2004. Pressure effects on Clostridium strains isolated from a cold deep-sea environment. Extremophiles 8, 169-173. http://dx.doi.org/10.1007/s00792-003-0367-y.

Lauro, F.M., Chastain, R.A., Blankenship, L.E., Yayanos, A.A., Bartlett, D.H., 2007. The unique 16S rRNA genes of piezophiles reflect both phylogeny and adaptation. Appl. Environ. Microbiol. 73, 838-845. http://dx.doi.org/10.1128/AEM.01726-06.

Lauro, F.M., Chastain, R.A., Ferriera, S., Johnson, J., Yayanos, A.A., Bartlett, D.H., 2013. Draft genome sequence of the deep-sea bacterium Shewanella benthica strain KT99. Genome Announc. 1, e00210-00213. http://dx.doi.org/10.1128/genomeA. 00210-13.

Li, G., Lai, Q., Du, Y., Liu, X., Sun, F., Shao, Z., 2015. Marinibacterium profundimaris gen. nov., sp. nov., isolated from deep seawater. Int. J. Syst. Evol. Microbiol. 65, 4175-4179. http://dx.doi.org/10.1099/ijsem.0.000557.

Li, S., Tang, K., Liu, K., Jiao, N., 2015. Thiobacimonas profunda gen. nov., sp. nov., a member of the family Rhodobacteraceae isolated from deep-sea water. Int. J. Syst. Evol. Microbiol. 65, 359-364. http://dx.doi.org/10.1099/ijs.0.066449-0.

Liesack, W., Weyland, H., Stackebrandt, E., 1991. Potential risks of gene amplification by PCR as determined by $16 \mathrm{~S}$ rDNA analysis of a mixed-culture of strict barophilic bacteria. Microb. Ecol. 21, 191-198. http://dx.doi.org/10.1007/BF02539153.

Ma, L., Kim, J., Hatzenpichler, R., Karymov, M.A., Hubert, N., Hanan, I.M., Chang, E.B., Ismagilov, R.F., 2014. Gene-targeted microfluidic cultivation validated by isolation of a gut bacterium listed in Human Microbiome Project's Most Wanted taxa. Proc. Natl. Acad. Sci. USA 111, 9768-9773. http://dx.doi.org/10.1073/pnas.1404753111.

Manome, A., Zhang, H., Tani, Y., Katsuragi, T., Kurane, R., Tsuchida, T., 2001. Application of gel microdroplet and flow cytometry techniques to selective enrichment of non-growing bacterial cells. FEMS Microbiol. Lett. 197, 29-33. http://dx.doi. org/10.1111/j.1574-6968.2001.tb10578.x.

Marteinsson, V.T., Birrien, J.-L., Reysenbach, A.-L., Vernet, M., Marie, D., Gambacorta, A., Messner, P., Sleytr, U.B., Prieur, D., 1999. Thermococcus barophilus sp. nov., a new barophilic and hyperthermophilic archaeon isolated under high hydrostatic pressure from a deep-sea hydrothermal vent. Int. J. Syst. Bacteriol. 49, 351-359. http://dx. doi.org/10.1099/00207713-49-2-351.

Martini, S., Al Ali, B., Garel, M., Nerini, D., Grossi, V., Pacton, M., Casalot, L., Cuny, P., Tamburini, C., 2013. Effects of hydrostatic pressure on growth and luminescence of a moderately-piezophilic luminous bacteria Photobacterium phosphoreum ANT-2200. PLoS One 8, e66580. http://dx.doi.org/10.1371/journal.pone.0066580.
Mino, S., Kudo, H., Arai, T., Sawabe, T., Takai, K., Nakagawa, S., 2014. Sulfurovum aggregans sp. nov., a hydrogen-oxidizing, thiosulfate-reducing chemolithoautotroph within the Epsilonproteobacteria isolated from a deep-sea hydrothermal vent chimney, and an emended description of the genus Sulfurovum. Int. J. Syst. Evol. Microbiol. 64, 3195-3201. http://dx.doi.org/10.1099/ijs.0.065094-0.

Miyazaki, M., Sakai, S., Yamanaka, Y., Saito, Y., Takai, K., Imachi, H., 2014. Spirochaeta psychrophila sp. nov., a psychrophilic spirochaete isolated from subseafloor sediment, and emended description of the genus Spirochaeta. Int. J. Syst. Evol. Microbiol. 64, 2798-2804. http://dx.doi.org/10.1099/ijs.0.062463-0.

Mizunoe, Y., Wai, S.N., Ishikawa, T., Takade, A., Yoshida, S.-i., 2000. Resuscitation of viable but nonculturable cells of Vibrio parahaemolyticus induced at low temperature under starvation. FEMS Microbiol. Lett. 186, 115-120. http://dx.doi.org/10.1111/j. 1574-6968.2000.tb09091.x.

Nakayama, A., Yano, Y., Yoshida, K., 1994. New method for isolating barophiles from intestinal contents of deep-sea fishes retrieved from the abyssal zone. Appl. Environ. Microbiol. 60, 4210-4212.

Nichols, D., Cahoon, N., Trakhtenberg, E.M., Pham, L., Mehta, A., Belanger, A., Kanigan, T., Lewis, K., Epstein, S.S., 2010. Use of ichip for high-throughput in situ cultivation of "uncultivable" microbial species. Appl. Environ. Microbiol. 76, 2445-2450. http://dx. doi.org/10.1128/AEM.01754-09.

Nichols, D., Lewis, K., Orjala, J., Mo, S., Ortenberg, R., O'Connor, P., Zhao, C., Vouros, P., Kaeberlein, T., Epstein, S.S., 2008. Short peptide induces an "uncultivable" microorganism to grow in vitro. Appl. Environ. Microbiol. 74, 4889-4897. http://dx.doi. org/10.1128/AEM.00393-08.

Nogi, Y., Hosoya, S., Kato, C., Horikoshi, K., 2004. Colwellia piezophila sp. nov., a novel piezophilic species from deep-sea sediments of the Japan Trench. Int. J. Syst. Evol. Microbiol. 54, 1627-1631. http://dx.doi.org/10.1099/ijs.0.03049-0.

Nogi, Y., Hosoya, S., Kato, C., Horikoshi, K., 2007. Psychromonas hadalis sp. nov., a novel piezophilic bacterium isolated from the bottom of the Japan Trench. Int. J. Syst. Evol. Microbiol. 57, 1360-1364. http://dx.doi.org/10.1099/ijs.0.64933-0.

Nogi, Y., Kato, C., 1999. Taxonomic studies of extremely barophilic bacteria isolated from the Mariana Trench and description of Moritella yayanosii sp. nov., a new barophilic bacterial isolate. Extremophiles 3, 71-77. http://dx.doi.org/10.1007/ s007920050101.

Nogi, Y., Kato, C., Horikoshi, K., 1998a. Moritella japonica sp, nov., a novel barophilic bacterium isolated from a Japan Trench sediment. J. Gen. Appl. Microbiol. 44, 289-295.

Nogi, Y., Kato, C., Horikoshi, K., 1998b. Taxonomic studies of deep-sea barophilic Shewanella strains and description of Shewanella violacea sp. nov. Arch. Microbiol. 170, 331-338. http://dx.doi.org/10.1007/s002030050650.

Nogi, Y., Kato, C., Horikoshi, K., 2002. Psychromonas kaikoae sp. nov., a novel from the deepest piezophilic bacterium cold-seep sediments in the Japan Trench. Int. J. Syst. Evol. Microbiol. 52, 1527-1532. http://dx.doi.org/10.1099/00207713-52-5-1527.

Nogi, Y., Masui, N., Kato, C., 1998c. Photobacterium profundum sp. nov., a new, moderately barophilic bacterial species isolated from a deep-sea sediment. Extremophiles 2, 1-7. http://dx.doi.org/10.1007/s007920050036.

Oger, P., Cario, A., 2013. The high pressure life of piezophiles. Biologie aujourd'hui 208, 193-206.

Olson, J.B., Lord, C.C., McCarthy, P.J., 2000. Improved recoverability of microbial colonies from marine sponge samples. Microb. Ecol. 40, 139-147. http://dx.doi.org/10. 1007/s002480000058.

Park, B.-J., Park, S.-J., Yoon, D.-N., Schouten, S., Sinninghe Damsté, J.S., Rhee, S.-K., 2010. Cultivation of autotrophic ammonia-oxidizing archaea from marine sediments in coculture with sulfur-oxidizing bacteria. Appl. Environ. Microbiol. 76, 7575-7587. http://dx.doi.org/10.1128/AEM.01478-10.

Park, K., 1966. Deep-sea pH. Science 154, 1540-1542. http://dx.doi.org/10.1126/ science.154.3756.1540.

Parkes, R.J., Sellek, G., Webster, G., Martin, D., Anders, E., Weightman, A.J., Sass, H., 2009. Culturable prokaryotic diversity of deep, gas hydrate sediments: first use of a continuous high-pressure, anaerobic, enrichment and isolation system for subseafloor sediments (DeepIsoBUG). Environ. Microbiol. 11, 3140-3153. http://dx.doi.org/10. 1111/j.1462-2920.2009.02018.x.

Pathom-aree, W., Nogi, Y., Sutcliffe, I.C., Ward, A.C., Horikoshi, K., Bull, A.T., Goodfellow, M., 2006. Dermacoccus abyssi sp. nov., a piezotolerant actinomycete isolated from the Mariana Trench. Int. J. Syst. Evol. Microbiol. 56, 1233-1237. http://dx.doi.org/10.1099/ijs.0.64133-0.

Qureshi, M.H., Kato, C., Horikoshi, K., 1998. Purification of a ccb-type quinol oxidase specifically induced in a deep-sea barophilic bacterium, Shewanella sp. strain DB172F. Extremophiles 2, 93-99. http://dx.doi.org/10.1007/s007920050047.

Radjasa, O.K., 2013. Phylogenetic relationship of barophilic bacteria from northwestern Pacific Ocean. J. Coast. Dev. 5, 35-40.

Rappé, M.S., Connon, S.A., Vergin, K.L., Giovannoni, S.J., 2002. Cultivation of the ubiquitous SAR11 marine bacterioplankton clade. Nature 418, 630-633. http://dx.doi. org/10.1038/nature00917.

Rüger, H.-J., Tan, T.L., 1992. Community structures of cold and low-nutrient adapted heterotrophic sediment bacteria from the deep eastern tropical Atlantic. Mar. Ecol. Prog. Ser. 84, 83-93.

Runko, G.M., Fang, J., Kato, C., 2014. Isolation and characterization of Gram-positive piezophilic bacteria from deep marine subsurface sediment. AGU Fall Meeting Abstracts 1, 1: 0138

Sakiyama, T., Ohwada, K., 1997. Isolation and growth characteristics of deep-sea barophilic bacteria from the Japan Trench. Fish. Sci. 63, 228-232.

Salazar, G., Cornejo-Castillo, F.M., Benítez-Barrios, V., Fraile-Nuez, E., Álvarez-Salgado, X.A., Duarte, C.M., Gasol, J.M., Acinas, S.G., 2016. Global diversity and biogeography of deep-sea pelagic prokaryotes. ISME J. 10, 596-608. http://dx.doi.org/10.1038/ ismej.2015.137. 
Schauer, R., Bienhold, C., Ramette, A., Harder, J., 2010. Bacterial diversity and biogeography in deep-sea surface sediments of the South Atlantic Ocean. ISME J. 4, 159-170. http://dx.doi.org/10.1038/ismej.2009.106.

Sekiguchi, T., Sato, T., Enoki, M., Kanehiro, H., Kato, C., 2010. Procedure for isolation of the plastic degrading piezophilic bacteria from deep-sea environments. J. Jpn. Soc. Extrem. 9, 25-30.

Shao, R., Lai, Q., Liu, X., Sun, F., Du, Y., Li, G., Shao, Z., 2014. Zunongwangia atlantica sp. nov., isolated from deep-sea water. Int. J. Syst. Evol. Microbiol. 64, 16-20. http://dx. doi.org/10.1099/ijs.0.054007-0.

Sizova, M.V., Hohmann, T., Hazen, A., Paster, B.J., Halem, S.R., Murphy, C.M., Panikov, N.S., Epstein, S.S., 2012. New approaches for isolation of previously uncultivated oral bacteria. Appl. Environ. Microbiol. 78, 194-203. http://dx.doi.org/10.1128/AEM. 06813-11.

Skropeta, D., Wei, L., 2014. Recent advances in deep-sea natural products. Nat. Prod. Rep. 31, 999-1025. http://dx.doi.org/10.1039/C3NP70118B.

Sogin, M.L., Morrison, H.G., Huber, J.A., Welch, D.M., Huse, S.M., Neal, P.R., Arrieta, J.M., Herndl, G.J., 2006. Microbial diversity in the deep sea and the underexplored "rare biosphere". Proc. Natl. Acad. Sci. USA 103, 12115-12120. http://dx.doi.org/ 10.1073/pnas.0605127103.

Song, J., Oh, H.-M., Cho, J.-C., 2009. Improved culturability of SAR11 strains in dilutionto-extinction culturing from the East Sea, West Pacific Ocean. FEMS Microbiol. Lett. 295, 141-147. http://dx.doi.org/10.1111/j.1574-6968.2009.01623.x.

Staley, J.T., Konopka, A., 1985. Measurement of in situ activities of nonphotosynthetic microorganisms in aquatic and terrestrial habitats. Annu. Rev. Microbiol. 39, 321-346. http://dx.doi.org/10.1146/annurev.mi.39.100185.001541.

Steinert, G., Whitfield, S., Taylor, M.W., Thoms, C., Schupp, P.J., 2014. Application of diffusion growth chambers for the cultivation of marine sponge-associated bacteria. Mar. Biotechnol. 16, 594-603. http://dx.doi.org/10.1007/s10126-014-9575-y.

Stevenson, B.S., Eichorst, S.A., Wertz, J.T., Schmidt, T.M., Breznak, J.A., 2004. New strategies for cultivation and detection of previously uncultured microbes. Appl. Environ. Microbiol. 70, 4748-4755. http://dx.doi.org/10.1128/AEM.70.8.47484755.2004.

Stingl, U., Tripp, H.J., Giovannoni, S.J., 2007. Improvements of high-throughput culturing yielded novel SAR11 strains and other abundant marine bacteria from the Oregon coast and the Bermuda Atlantic Time Series study site. ISME J. 1, 361-371. http://dx.doi.org/10.1038/ismej.2007.49.

Stott, M.B., Crowe, M.A., Mountain, B.W., Smirnova, A.V., Hou, S., Alam, M., Dunfield, P.F., 2008. Isolation of novel bacteria, including a candidate division, from geothermal soils in New Zealand. Environ. Microbiol. 10, 2030-2041. http://dx.doi.org/ 10.1111/j.1462-2920.2008.01621.x.

Takai, K., Horikoshi, K., 2000. Thermosipho japonicus sp. nov., an extremely thermophilic bacterium isolated from a deep-sea hydrothermal vent in Japan. Extremophiles 4, 9-17. http://dx.doi.org/10.1007/s007920050002.

Takai, K., Miyazaki, M., Hirayama, H., Nakagawa, S., Querellou, J., Godfroy, A., 2009. Isolation and physiological characterization of two novel, piezophilic, thermophilic chemolithoautotrophs from a deep-sea hydrothermal vent chimney. Environ. Microbiol. 11, 1983-1997. http://dx.doi.org/10.1111/j.1462-2920.2009.01921.x.

Takai, K., Nakamura, K., Toki, T., Tsunogai, U., Miyazaki, M., Miyazaki, J., Hirayama, H., Nakagawa, S., Nunoura, T., Horikoshi, K., 2008. Cell proliferation at $122^{\circ} \mathrm{C}$ and isotopically heavy $\mathrm{CH}_{4}$ production by a hyperthermophilic methanogen under highpressure cultivation. Proc. Natl. Acad. Sci. USA 105, 10949-10954. http://dx.doi. org/10.1073/pnas.0712334105.

Takai, K., Sugai, A., Itoh, T., Horikoshi, K., 2000. Palaeococcus ferrophilus gen. nov., sp. nov., a barophilic, hyperthermophilic archaeon from a deep-sea hydrothermal vent chimney. Int. J. Syst. Evol. Microbiol. 50, 489-500. http://dx.doi.org/10.1099/ 00207713-50-2-489.

Takami, H., Inoue, A., Fuji, F., Horikoshi, K., 1997. Microbial flora in the deepest sea mud of the Mariana Trench. FEMS Microbiol. Lett. 152, 279-285. http://dx.doi.org/10. 1111/j.1574-6968.1997.tb10440.x.

Tamaki, H., Sekiguchi, Y., Hanada, S., Nakamura, K., Nomura, N., Matsumura, M. Kamagata, Y., 2005. Comparative analysis of bacterial diversity in freshwater sediment of a shallow eutrophic lake by molecular and improved cultivation-based techniques. Appl. Environ. Microbiol. 71, 2162-2169. http://dx.doi.org/10.1128/ AEM.71.4.2162-2169.2005.

Tan, C., Ding, K., Jin, B., Seyfried, W.E., Chen, Y., 2012. Development of an in situ pH calibrator in deep sea environments. IEEE/ASME Trans. Mechatron. 17, 8-15. http:// dx.doi.org/10.1109/TMECH.2011.2168419.

Toffin, L., Bidault, A., Pignet, P., Tindall, B.J., Slobodkin, A., Kato, C., Prieur, D., 2004 Shewanella profunda sp. nov., isolated from deep marine sediment of the Nankai Trough. Int. J. Syst. Evol. Microbiol. 54, 1943-1949. http://dx.doi.org/10.1099/ijs. 0.03007-0.

Tripp, H.J., Kitner, J.B., Schwalbach, M.S., Dacey, J.W.H., Wilhelm, L.J., Giovannoni, S.J., 2008. SAR11 marine bacteria require exogenous reduced sulphur for growth. Nature 452, 741-744. http://dx.doi.org/10.1038/nature06776.

Tsubouchi, T., Koyama, S., Mori, K., Shimane, Y., Usui, K., Tokuda, M., Tame, A., Uematsu, K., Maruyama, T., Hatada, Y., 2014. Brevundimonas denitrificans sp. nov., a denitrifying bacterium isolated from deep subseafloor sediment. Int. J. Syst. Evol. Microbiol. 64, 3709-3716. http://dx.doi.org/10.1099/ijs.0.067199-0.

Uphoff, H.U., Felske, A., Fehr, W., Wagner-Döbler, I., 2001. The microbial diversity in picoplankton enrichment cultures: a molecular screening of marine isolates. FEMS Microbiol. Ecol. 35, 249-258. http://dx.doi.org/10.1111/j.1574-6941.2001. tb00810.x.
Vancanneyt, M., Schut, F., Snauwaert, C., Goris, J., Swings, J., Gottschal, J.C., 2001. Sphingomonas alaskensis sp. nov., a dominant bacterium from a marine oligotrophic environment. Int. J. Syst. Evol. Microbiol. 51, 73-79. http://dx.doi.org/10.1099/ 00207713-51-1-73.

Weng, C.-Y., Chen, S.-C., Lai, M.-C., Wu, S.-Y., Lin, S., Yang, T.F., Chen, P.-C., 2015. Methanoculleus taiwanensis sp. nov., a methanogen isolated from deep marine sediment at the deformation front area near Taiwan. Int. J. Syst. Evol. Microbiol. 65, 1044-1049. http://dx.doi.org/10.1099/ijs.0.000062.

Wirsen, C.O., Jannasch, H.W., Wakeham, S.G., Canuel, E.A., 1986. Membrane lipids of a psychrophilic and barophilic deep-sea bacterium. Curr. Microbiol. 14, 319-322.

Wu, Y.-H., Xu, L., Meng, F.-X., Zhang, D.-S., Wang, C.-S., Oren, A., Xu, X.-W., 2014 Altererythrobacter atlanticus sp. nov., isolated from deep-sea sediment. Int. J. Syst. Evol. Microbiol. 64, 116-121. http://dx.doi.org/10.1099/ijs.0.052951-0.

Xiao, X., Wang, P., Zeng, X., Bartlett, D.H., Wang, F., 2007. Shewanella psychrophila sp. nov. and Shewanella piezotolerans sp. nov., isolated from west Pacific deep-sea sediment. Int. J. Syst. Evol. Microbiol. 57, 60-65. http://dx.doi.org/10.1099/ijs.0. 64500-0.

Xin, Y., Kanagasabhapathy, M., Janussen, D., Xue, S., Zhang, W., 2011. Phylogenetic diversity of Gram-positive bacteria cultured from Antarctic deep-sea sponges. Polar Biol. 34, 1501-1512. http://dx.doi.org/10.1007/s00300-011-1009-y.

Xu, H., Jiang, L., Li, S., Zeng, X., Shao, Z., 2015. Mameliella atlantica sp. nov., a marine bacterium of the Roseobacter clade isolated from deep-sea sediment of the South Atlantic Ocean. Int. J. Syst. Evol. Microbiol. 65, 2255-2259. http://dx.doi.org/10 1099/ijs.0.000248.

Xu, Y., Nogi, Y., Kato, C., Liang, Z., Rüger, H.-J., De Kegel, D., Glansdorff, N., 2003a. Moritella profunda sp. nov. and Moritella abyssi sp. nov., two psychropiezophilic organisms isolated from deep Atlantic sediments. Int. J. Syst. Evol. Microbiol. 53, 533-538. http://dx.doi.org/10.1099/ijs.0.02228-0.

Xu, Y., Nogi, Y., Kato, C., Liang, Z., Rüger, H.-J., De Kegel, D., Glansdorff, N., 2003b. Psychromonas profunda sp. nov., a psychropiezophilic bacterium from deep Atlantic sediments. Int. J. Syst. Evol. Microbiol. 53, 527-532. http://dx.doi.org/10.1099/ijs. $0.02227-0$

Yano, Y., Nakayama, A., Yoshida, K., 1997. Distribution of polyunsaturated fatty acids in bacteria present in intestines of deep-sea fish and shallow-sea poikilothermic animals. Appl. Environ. Microbiol. 63, 2572-2577.

Yayanos, A.A., 1986. Evolutional and ecological implications of the properties of deep-sea barophilic bacteria. Proc. Natl. Acad. Sci. USA 83, 9542-9546.

Yayanos, A.A., Dietz, A.S., Van Boxtel, R., 1979. Isolation of a deep-sea barophilic bacterium and some of its growth characteristics. Science 205, 808-810. http://dx.doi. org/10.1126/science.205.4408.808.

Yayanos, A.A., Dietz, A.S., Van Boxtel, R., 1981. Obligately barophilic bacterium from the Mariana trench. Proc. Natl. Acad. Sci. USA 78, 5212-5215.

Yayanos, A.A., Dietz, A.S., Van Boxtel, R., 1982. Dependence of reproduction rate on pressure as a hallmark of deep-sea bacteria. Appl. Environ. Microbiol. 44 1356-1361.

Yu, C., Yu, S., Zhang, Z., Li, Z., Zhang, X.-H., 2014. Oceanobacillus pacificus sp. nov., isolated from a deep-sea sediment. Int. J. Syst. Evol. Microbiol. 64, 1278-1283. http://dx.doi.org/10.1099/ijs.0.056481-0.

Zeng, X., Birrien, J.-L., Fouquet, Y., Cherkashov, G., Jebbar, M., Querellou, J., Oger, P., Cambon-Bonavita, M.-A., Xiao, X., Prieur, D., 2009. Pyrococcus CH1, an obligate piezophilic hyperthermophile: extending the upper pressure-temperature limits for life. ISME J. 3, 873-876. http://dx.doi.org/10.1038/ismej.2009.21.

Zeng, X., Zhang, X., Jiang, L., Alain, K., Jebbar, M., Shao, Z., 2013. Palaeococcus pacificus sp. nov., an archaeon from deep-sea hydrothermal sediment. Int. J. Syst. Evol. Microbiol. 63, 2155-2159. http://dx.doi.org/10.1099/ijs.0.044487-0.

Zeng, X., Zhang, Z., Li, X., Jebbar, M., Alain, K., Shao, Z., 2015a. Caloranaerobacter ferrireducens sp. nov., an anaerobic, thermophilic, iron (III)-reducing bacterium isolated from deep-sea hydrothermal sulfide deposits. Int. J. Syst. Evol. Microbiol. 65, 1714-1718. http://dx.doi.org/10.1099/ijs.0.000165.

Zeng, X., Zhang, Z., Li, X., Zhang, X., Cao, J., Jebbar, M., Alain, K., Shao, Z., 2015b. Anoxybacter fermentans gen. nov., sp. nov., a piezophilic, thermophilic, anaerobic, fermentative bacterium isolated from a deep-sea hydrothermal vent. Int. J. Syst. Evol. Microbiol. 65, 710-715. http://dx.doi.org/10.1099/ijs.0.068221-0.

Zengler, K., Toledo, G., Rappe, M., Elkins, J., Mathur, E.J., Short, J.M., Keller, M., 2002 Cultivating the uncultured. Proc. Natl. Acad. Sci. USA 99, 15681-15686. http://dx. doi.org/10.1073/pnas.252630999.

Zengler, K., Walcher, M., Clark, G., Haller, I., Toledo, G., Holland, T., Mathur, E.J., Woodnutt, G., Short, J.M., Keller, M., 2005. High-throughput cultivation of microorganisms using microcapsules. Methods Enzymol. 397, 124-130. http://dx.doi.org/ 10.1016/S0076-6879(05)97007-9.

Zhang, Y., Li, J., Tian, X., Zhang, S., 2015. Marinithermofilum abyssi gen. nov., sp. nov. and Desmospora profundinema sp. nov., isolated from a deep-sea sediment, and emended description of the genus Desmospora Yassin et al. 2009. Int. J. Syst. Evol. Microbiol. 65, 2622-2629. http://dx.doi.org/10.1099/ijs.0.000314.

Zhang, Z., Fan, X., Gao, X., Zhang, X.-H., 2014. Achromobacter sediminum sp. nov., isolated from deep subseafloor sediment of South Pacific Gyre. Int. J. Syst. Evol. Microbiol. 64, 2244-2249. http://dx.doi.org/10.1099/ijs.0.062265-0.

Zhao, W., Zeng, X., Xiao, X., 2015. Thermococcus eurythermalis sp. nov., a conditional piezophilic, hyperthermophilic archaeon with a wide temperature range for growth, isolated from an oil-immersed chimney in the Guaymas Basin. Int. J. Syst. Evol. Microbiol. 65, 30-35. http://dx.doi.org/10.1099/ijs.0.067942-0.

ZoBell, C.E., Morita, R.Y., 1959. Deep-sea bacteria. Galathea Rep. 1, pp.139-154. 